\title{
Virus infections in children with acute lymphoblastic leukaemia
}

\author{
A. W. CRAFT, M. M. REID, P. S. GARDNER, E. JACKSON, J. KERNAHAN, J. MCQUILLIN, \\ T. C. NOBLE, AND W. WALKER
}

Departments of Child Health, Virology, and Haematology, Royal Victoria Infirmary, Newcastle upon Tyne, and the Children's Department, Newcastle General Hospital

SUMMARY The pattern of virus isolation and illness was studied in 64 children with acute lymphoblastic leukaemia (ALL) during periods of apparent infection and when the children were well. The virus isolation rate of $2 \cdot 2$ viruses per child a year is similar to that previously found in normal children. In only $32 \%$ of children with symptoms were viruses found and $14.5 \%$ had viruses isolated when asymptomatic. The children with ALL appear to be more vulnerable to multiple virus infections and to excrete the virus for longer periods. This may be due to failure of production of both local and systemic antibodies. The failure in the past to recognise the true importance of virus infections in ALL may have been due to inadequate diagnostic techniques.

Infections are playing an increasingly important role in the death of children with acute lymphoblastic leukaemia (ALL) and viruses are emerging as important pathogens (Craft et al., 1977). While it is recognised that varicella zoster and measles may be particularly severe in the immunosuppressed host (Feldman and Cox, 1976), it has been suggested that the common upper respiratory virus infections are neither more frequent nor more severe in children with ALL (Levine et al., 1974). However, there has been little systematic study of virus infections in this disease. In the present investigation viruses were studied in children with ALL, both when an infection was suspected and when the children were well. The results are presented in the light of locally acquired experience of virus infections in normal children.

\footnotetext{
Royal Victoria Infirmary, Newcastle upon Tyne

Department of Paediatrics

A. W. CRAFT, consultant paediatrician

Department of Haematology

M. M. REID, senior registrar

J. KERNAHAN, senior registrar

W. WALKER, professor of haematology

Department of Pathology

E. JACKSON, research associate

Department of Virology

J. MCQUiLLIN, principal scientific officer

Department of Paediatrics, Newcastle General Hospital,

T. C. NOBLE, consultant paediatrician

Division of Microbiological Reagents and Quality Control,

Central Public Health Laboratory, London

P. S. GARDNER, director
}

\section{Patients and methods}

64 children with ALL, 34 boys and 30 girls, were followed for at least 2 months, some for as long as 33 months. Their ages at diagnosis ranged from $1 \frac{1}{2}$ to 14 years. All were being treated with conventional combination chemotherapy and prophylactic cranial irradiation and most were on a modified ALGB 6801 regimen (Reid et al., 1977). During the initial phase of the investigation children were studied only when they were suspected of having an infection. 31 such children were followed for a total of 468 patient months. The remaining 33 children were investigated when they were infected and also routinely at monthly intervals. They were followed for a total of 397 patient months. When an infection was suspected a specimen of nasopharyngeal secretion was investigated by the fluorescent antibody technique (FAT) (Gardner and McQuillin, 1974). Nose and throat swabs were obtained at the same time and cultured for viruses. The routine monthly investigations consisted only of nose and throat swabs. Varicella zoster was identified by fluorescent antibody staining of scrapings of skin lesions. All isolations by the FAT were confirmed by subsequent culture. No attempt was made to isolate viruses from faeces or urine. Whenever possible further specimens were taken after the initial diagnosis of a virus infection until the child ceased to excrete the virus. Specimens of blood both in the acute and convalescent phases were taken from many of the patients 
and the titre of complement fixing antibody to the isolated virus was determined.

The clinical features of the illnesses caused by viruses were divided according to whether or not the child was asymptomatic, had a mild to moderate illness which was not more severe than would be expected in a normal child and for which admission to hospital was not required, symptoms which were much more severe than usual requiring admission to hospital and often life threatening, and those which were associated with the death of the child although not necessarily the direct cause of death.

\section{Controls}

Control information was obtained from normal children admitted to local hospitals in recent years because of a virus infection and investigated using identical techniques in the same laboratory as in this study. A group of 796 normal children was studied to define the rate of multiple virus isolation in a single infective episode.

The length of time for which influenza A, respiratory syncytial virus (RSV), or measles was excreted by normal children was obtained by examination of follow-up specimens taken after the diagnosis of the infection. Generally no further specimen was taken after the child was clinically well or discharged from hospital.

The pattern of rise of complement fixing antibodies to influenza $\mathbf{A}$ and measles in normal children was obtained from the same group of children, but for RSV the control data were confined to those older than one year. However, the effect of local nasopharyngeal blocking antibodies on the rate of isolation of RSV from normal children (Gardner and McQuillin, 1978) was studied in children of all ages.

\section{Results}

During the initial phase of the investigations 31 patients were followed for a total of 468 patient months and 46 viruses were obtained, with an isolation rate of 1.2 viruses per child a year. The remaining 33 children, who were also swabbed routinely at monthly intervals, were followed for 397 patient months and 73 viruses were isolated, an isolation rate of $2 \cdot 2$ viruses per child a year. 119 viruses were isolated from 50 of the 64 children during 99 infective episodes. 14 were at no time infected with a virus that could be detected by these techniques. The viruses isolated and the severity of illnesses are shown in Table 1.15 children had 21 severe illnesses associated with virus infections and clinical details of these are shown in Table 2. The 33 asymptomatic virus isolations were all made during the second phase of the study. In many of the children who had symptoms suggesting a virus infection it was not possible to isolate one, and the relationship between the presence of symptoms and the isolation of virus is shown in Table 3.

18 children had more than one virus isolated during the same illness, 15 had a dual infection once, 2 on two occasions, and 1 child had three viruses isolated simultaneously. Multiple virus isolations were therefore present in $20(20 \%)$ of the 99 episodes of virus infection. There were 20 multiple virus isolations in the 796 normal children, a rate of $2.5 \%$. This difference is significant $\left(\chi^{2}=66 \cdot 5, P<0 \cdot 001\right)$.

The length of time of excretion of RSV, influenza $A$, and measles is shown in Fig. 1 and is compared with data from normal children.

The antibody titres to RSV, influenza $A$, and measles during the acute and convalescent phases of the illness are compared with those from a group of normal children in Fig. 2.

Table 1 Viruses isolated according to the severity of illness

\begin{tabular}{|c|c|c|c|c|c|}
\hline Virus & Asymptomatic & $\begin{array}{l}\text { Mild to moderate } \\
\text { illness- } \\
\text { not admitted }\end{array}$ & $\begin{array}{l}\text { Severe illness- } \\
\text { admitted }\end{array}$ & $\begin{array}{l}\text { Associated with } \\
\text { death }\end{array}$ & Total \\
\hline H-strain rhinovirus & 13 & 16 & 4 & 4 & 37 \\
\hline Herpes virus hominis & 13 & 10 & 3 & & 26 \\
\hline Cytomegalovirus & 5 & 1 & 4 & 2 & 12 \\
\hline Respiratory syncytial virus & 1 & 7 & 2 & & 10 \\
\hline \multicolumn{6}{|l|}{ Influenza } \\
\hline A & & 6 & 5 & & 11 \\
\hline B & & 2 & & & 2 \\
\hline \multicolumn{6}{|l|}{ Parainfluenza } \\
\hline 3 & & 1 & 1 & 1 & 3 \\
\hline 4 & & & 1 & & 1 \\
\hline Adenovirus & 1 & 5 & & & 6 \\
\hline Measles & & & 2 & 1 & 3 \\
\hline Echovirus & & 1 & 3 & & 4 \\
\hline Varicella zoster & & 2 & & & 2 \\
\hline Mumps & & 1 & & 1 & 2 \\
\hline
\end{tabular}


Table 2 Clinical details of children who had a severe illness and were admitted to hospital

\begin{tabular}{|c|c|c|c|c|}
\hline Case & & Main clinical details & $\begin{array}{l}\text { Length of } \\
\text { illness } \\
\text { (days) }\end{array}$ & Virus isolated \\
\hline \multirow[t]{3}{*}{1} & September 1976 & Pneumonitis, prolonged fever* & 21 & Cytomegalovirus \\
\hline & November 1976 & Fever, cough, petechial rash & 4 & H-strain rhinovirus \\
\hline & February 1977 & Pneumonitis, fever & 7 & Influenza $\mathbf{A}$ \\
\hline \multirow[t]{2}{*}{2} & July 1976 & Fever, rash, splenomegaly & 14 & Cytomegalovirus \\
\hline & August 1976 & URTI, hepatosplenomegaly & 14 & H-strain rhinovirus \\
\hline \multirow[t]{2}{*}{3} & February 1976 & Pneumonitis, otitis media, fever* & 60 & Respiratory syncytial virus $+\mathrm{H}$-strain rhinovirus \\
\hline & February 1977 & Pneumonitis, otitis media, fever* & 60 & Respiratory syncytial virus + H-strain rhinovirus \\
\hline \multirow[t]{2}{*}{4} & August 1976 & Pneumonitis, oral ulceration, fever & 28 & Herpes virus hominis \\
\hline & March 1977 & Pneumonitis, otitis media, fever & 11 & Influenza A \\
\hline \multicolumn{2}{|r|}{ (t) } & Otitis media, fever, rash & 28 & Cytomegalovirus $+\mathrm{H}$-strain rhinovirus \\
\hline \multicolumn{2}{|l|}{6} & URTI, fever, otitis media, meningitis* & 12 & $\begin{array}{l}\text { Influenza A (also Listeria monocytogenes } \\
\text { meningitis) }\end{array}$ \\
\hline \multicolumn{2}{|l|}{7} & $\begin{array}{l}\text { Gastroenteritis, oral ulceration, } \\
\text { haematemesis* }\end{array}$ & 10 & $\begin{array}{l}\text { Herpes virus hominis (also Escherichia coli } \\
\text { septicaemia) }\end{array}$ \\
\hline \multicolumn{2}{|l|}{8} & Severe pneumonitis* & 26 & Measles \\
\hline \multicolumn{2}{|l|}{9} & Pneumonitis, no rash & 14 & Measles \\
\hline \multicolumn{2}{|l|}{11} & Fever, URTI, diarrhoea, abdominal pain & 42 & Parainfluenza 4 \\
\hline \multicolumn{2}{|l|}{12} & URTI, fever & 4 & Echovirus \\
\hline \multicolumn{2}{|l|}{$\begin{array}{l}13 \\
14\end{array}$} & Pneumonitis, fever, headache* & 10 & Parainfluenza 3 \\
\hline \multirow{2}{*}{\multicolumn{2}{|c|}{14}} & URTI, fever, cough, cervical & & \\
\hline & & lymphadenopathy* & 28 & Influenza A \\
\hline \multicolumn{2}{|l|}{15} & Pneumonia, anorexia, prolonged fever* & 35 & Echovirus and cytomegalovirus \\
\hline
\end{tabular}

URTI = Upper respiratory tract infection.

*Life threatening.

Table 3 Relationship between the presence or absence of symptoms suggestive of a virus infection and the isolation of a virus

\begin{tabular}{lcc}
\hline Virus & $\begin{array}{l}\text { Symptoms suggestive } \\
\text { of virus infection }\end{array}$ & No symptoms \\
\hline Isolated & 86 & 33 \\
Not isolated & 185 & 183 \\
\hline
\end{tabular}

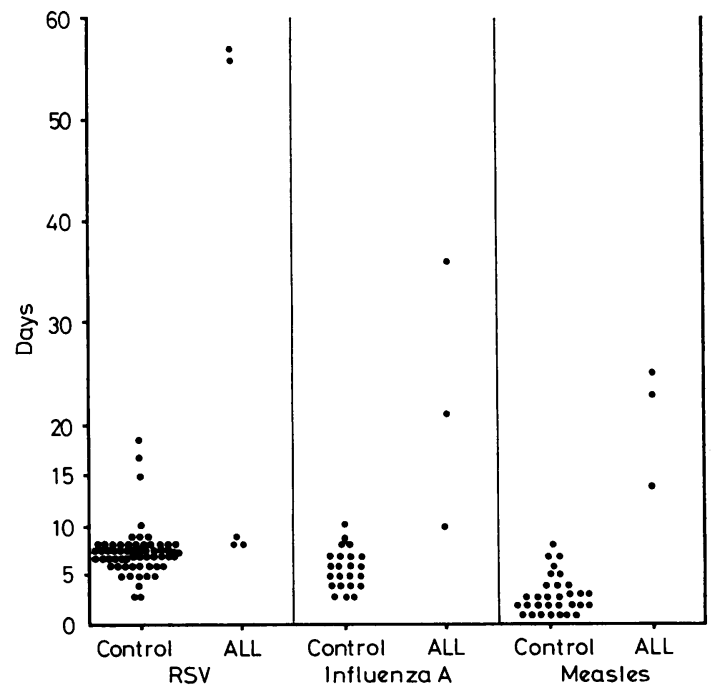

Fig. 1 Length of excretion of $R S V$, influenza $A$, and measles virus in normal children and those with leukaemia.
In the 5 children with RSV in whom follow-up specimens were taken it was possible to grow the virus as well as to demonstrate it by the FAT. However, of 150 normal children in whom RSV was demonstrated by the FAT in a follow-up specimen it was possible to grow the virus in only 59.

\section{Discussion}

There is very little information about the incidence of virus infections in normal children. Hurrell et al. (1971) studied two normal families at weekly intervals for a period of almost 2 years and found a virus isolation rate in the children of $2 \cdot 3$ viruses per child a year. The only other reported survey of virus infections in normal children is from the Seattle Virus Watch Programme but it is difficult to obtain a clear picture of virus isolation rates (Elveback et al., 1966). The isolation rate of $2 \cdot 2$ viruses per child a year, during the second phase of the current study suggests that children with leukaemia may not be more susceptible than normal children to virus infections, although the isolation rate might have been higher had they been swabbed at weekly intervals. However, previous studies have included many children less than one-year old, whereas most of the children with ALL were considerably older than this. Young children are known to suffer from more respiratory infections than older ones (Miller et al., 1974). Until more is known about viruses in the normal population it will not be 


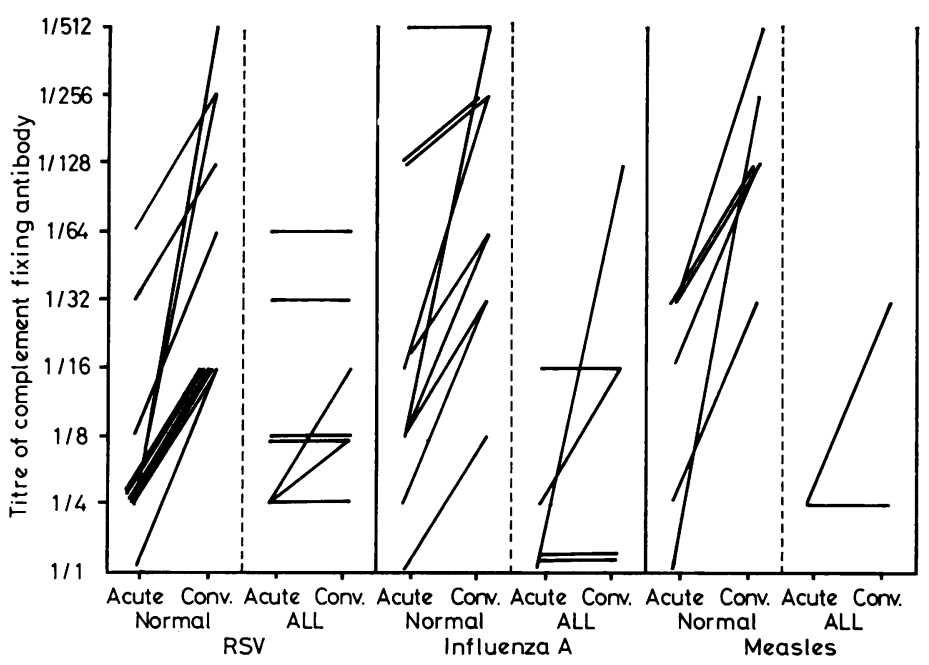

Fig. 2 Titre of complement fixing antibody to $R S V$, influenza $A$, and measles virus in acute and convalescent phases of illness in normal children and those with leukaemia. possible to be certain about the susceptibility of children with ALL to these infections.

The isolation of viruses from asymptomatic children, and the failure to isolate a virus from an apparently infected child, are both well recognised phenomena (Elveback et al., 1966). Elveback suggested that asymptomatic infections and excretion of virus were more common in younger than in older c.iildren. In the present study a virus was isolated from 0.1 ly $32 \%$ of the children with symptoms suggesting a virus infection. A virus was isolated from $15 \cdot 3 \%$ of the routine swabs taken from asymptomatic children. It is difficult to compare these results with those obtained from the Seattle Virus Watch Programme because of differences in the techniques used for isolation and, in particular, because faecal specimens were also collected in the American study. However, it is clear that many children suffer upper respiratory tract infections whose cause, at present, remains unknown and also that apparently well children may be asymptomatic carriers of, in particular, cytomegalovirus, herpesvirus, and rhinovirus. Many of the illnesses were no more serious than similar virus infections in normal children. However, severe illnesses, which were often life threatening, were associated with 25 of the viruses isolated. Many of these children had prolonged illnesses necessitating interruption of their leukaemia treatment.

Nine viruses were associated with 6 deaths. The role of viruses in the death of children with ALL has been discussed in detail (Craft et al., 1977).

Concurrent multiple virus isolations appear to be more common in children with ALL than in normal children, and this aspect of the study is being reported in detail elsewhere (Bruce et al., 1979).
The apparently increased susceptibility of children to multiple virus infections may be associated with prolonged excretion of viruses in many cases. Most normal children who have measles will have ceased to excrete virus by 3 or 4 days after the appearance of the rash and in a review from this laboratory none excreted for longer than 10 days (McQuillin et al., 1976). Influenza viruses are not normally excreted for more than 9 days in children (Brocklebank et al., 1972) and for only 3 or 4 days in adults (Knight et al., 1970), whereas the children with ALL did so for much longer. Most children with RSV stop excreting the virus by 10 days. Although there is a great deal of information about RSV in normal children in Newcastle, much of this has been acquired from infants less than one-year old (Gardner, 1976). Older children rarely develop infections severe enough to require admission to hospital and they also excrete the virus for a shorter period of time than do infants (Hall et al., 1976). All the children with ALL were older than one year, but some developed severe infections similar to those seen in normal infants. One child in the present study continued to excrete RSV for 56 and 57 days in two separate infective episodes one year apart. Rhinoviruses may be excreted for prolonged periods in normal children (Fox et al., 1975) as was found in the children with ALL.

Changes in complex immunological mechanisms probably account for the increased severity and prolonged excretion of viruses in children with ALL. In the current study we have been able to look at two aspects of the immune system. In only 59 of 150 children in whom RSV was demonstrated by the FAT was it possible to grow the virus. Complex immunofluorescent staining techniques have shown 
that this is due to the production of local blocking antibodies which prevent replication of the virus but do not prevent its demonstration by the FAT (McQuillin et al., 1970; Gardner and McQuillin, 1978). In the 5 children with leukaemia and RSV infection, follow-up specimens were all positive by both the FAT and viral culture and it was not possible to detect any local blocking antibodies. This failure of production of antibody to RSV is also shown serologically. Fig. 2 shows that all normal children with this infection produced a significant rise in the titre of complement fixing antibodies, compared with only 2 out of the 7 children with ALL. However, the situation with regard to other viruses is not as obvious and that for measles is complicated by the administration of pooled immunoglobulin. Borella and Webster (1971) reported impairment of the immune response to viral infection in patients with leukaemia. Bosu et al. (1975) studied the antibody response to polio virus immunisation in children with leukaemia and demonstrated a uniform failure of IgM response which they felt was independent of the leukaemia treatment, since it was still present in children in whom treatment had been stopped for at least 6 months.

The diagnosis of a viral infection has in the past depended to a large extent upon the demonstration of a rise in the titre of specific antibodies. The antibody rise which occurs in normal children may not occur in children with leukaemia, and this may have resulted in the past in the failure to recognise the true importance of virus infections in leukaemia.

We are grateful to the Tyneside Leukaemia Research Association for financial support.

\section{References}

Borella, L., and Webster, R. G. (1971). The immunosuppressive effects of long-term combination chemotherapy in children with acute leukaemia in remission. Cancer Research, 31, 420-426.

Bosu, S. K., Ciudad, H., Sinks, L. F., and Ogra, P. I. (1975). Antibody response to polio virus immunisation in childhood leukaemia. Medical and Pediatric Oncology, 1, 217-225.

Brocklebank, J. T., Court, S. D. M., McQuillin, J., and Gardner, P. S. (1972). Influenza-A infection in children. Lancet, 2, 497-500.

Bruce, E., Reid, M. M., Craft, A. W., Kernahan, J., and Gardner, P. S. (1979). Multiple virus infections in children with leukaemia. Journal of Infection, 1, 243-248.
Craft, A. W., Reid, M. M., Bruce, E., Kernahan, J., and Gardner, P. S. (1977). Role of infection in the death of children with acute lymphoblastic leukaemia. Archives of Disease in Childhood, 52, 752-757.

Elveback, L. R., Fox, J. P., Ketler, A., Brandt, C. D., Wasserman, F. E., and Hall, C. E. (1966). The virus watch program: a continuing surveillance of viral infections in metropolitan New York families. American Journal of Epidemiology, 83, 436-454.

Feldman, S., and Cox, F. (1976). Viral infections and haematological malignancies. Clinics in Haematology, 5, 311-328.

Fox, J. P., Cooney, M. K., and Hall, C. E. (1975). The Seattle virus watch. V. Epidemiologic observations of rhinovirus infections, 1965-1969, in families with young children. American Journal of Epidemiology, 101, 122-143.

Gardner, P. S. (1976). Viruses and respiratory infection in childhood. Proceedings of the Royal Society of Medicine, 69, 687-692.

Gardner, P. S., and McQuillin, J. (1974). Rapid Virus Diagnosis. Application of Immunofluorescence. Butterworth: London.

Gardner, P. S., and McQuillin, J. (1978). The coating of respiratory syncytial (RS) virus-infected cells in the respiratory tract by immunoglobulins. Journal of Medical Virology, 2, 165-173.

Hall, C. B., Geiman, J. M., Biggar, R., Kotok, D. I., Hogan, P. M., and Douglas, R. G., Jr (1976). Respiratory syncytial virus infections within families. New England Journal of Medicine, 294, 414-419.

Hurrell, G. D., Sturdy, P. M., Frood, J. D. L., and Gardner, P. S. (1971). Viruses in families. Lancet, 1, 769-774.

Knight, V., Fedson, D., Baldini, J., Gordon Douglas, R., and Couch, R. B. (1970). Amantadine therapy of epidemic influenza $\mathrm{A}_{2}$ (Hong Kong). Infection and Immunity, 1, 200-204.

Levine, A. S., Schimpff, S. C., Graw, R. G., and Young, T. C. (1974). Hematologic malignancies and other marrow failure states; progress in the management of complicating infections. Seminars in Hematology, 11, 141-202.

McQuillin, J., Gardner, P. S., and McGuckin, R. (1970). Rapid diagnosis of influenza by immunofluorescence techniques. Lancet, 2, 690-695.

McQuillin, J., Bell, T. M., Gardner, P. S., and Downham, M. A. P. S. (1976). Application of immunofluorescence to a study of measles. Archives of Disease in Childhood, 51, 411-419.

Miller, F. J. W., Court, S. D. M., Knox, E. G., and Brandon, S. (1974). The School Years in Newcastle upon Tyne. Oxford University Press: London.

Reid, M. M., Craft, A. W., and Todd, J. A. (1977). Serial studies of numbers of circulating $T$ and $B$ lymphocytes in children with acute lymphoblastic leukaemia. Archives of Disease in Childhood, 52, 245-247.

Correspondence to Dr A. W. Craft, Department of Child Health, Royal Victoria Infirmary, Queen Victoria Road, Newcastle upon Tyne NE1 4LP.

Received 1 February 1979 